\section{角 Heighten Science \\ P U B L I C A T I O N S Corporation ISSN 2639-6769}

Opinion

\title{
Medical bioethics vs. Medical ethics*
}

\author{
José Ma Barrio Maestre* \\ Professor of Complutense University, Madrid, Spain
}

\section{The anthropological crisis of bioethics}

The current situation of bioethics illustrates what has become known as "the anthropological halt", described with great lucidity by C. S. Lewis in his book The Abolition of Man as the neglect of the "Tao", a not very extensive body of basic axioms which enable the overall integrity of reason, both in theory and practice. One of these principles, visible to everyone and which provide the cornerstones of the JudeoChristian tradition, is the sanctity of human life.

The ancient Greek used the term aidos to refer to a feeling of reverent fear at crossing the limit, a basic shame before what is beyond us, outside our scope of availability, and therefore out of our reach to vary or change at will (nicht zu Handen, the German say).

From the perspective of his "philosophical" agnosticism, Kant has also seen the clear outlines of this limit. The German master, who, as is well known, is not a father of the Church, has no qualms to use the term sakral to refer to the untouchable nature -sacred- of the value of the human being an inhabitant of the "Kingdom of Ends" (Reich der Zwecke). This intrinsic value, he claims, is what we understand as dignity (innere Wert, d.h. Würde), which he clearly distinguishes from the extrinsic value or "price" (außere Wert, d.h. Preis). The value of a person never resides in the way in which he/she is appreciated or valued by others, or even by him/herself. Understood as the intrinsic value of the only realities that exist "for themselves" (ends in themselves, never mere means), this dignity is referred to by other philosophers -not by Kant, who disowns the term- as ontological dignity, in order to distinguish it from moral dignity, which lies in ethical nobility. However, this is somewhat inconsistent. The confidence with which the German master declares the absolute -unconditional- nature of the duty to respect the person is not in tune with the theoretical fragility of the notion of dignity, a metaphysical concept. There is, let's say, an insurmountable discontinuity between the ethical and the ontological, and the lineage of post-Kantian thought reveals that it has not been entirely innocent regarding certain insufficiencies and practical blurring.

The issue of the limit of our availability has also been incisively questioned by the German philosopher Anselm Winfried Müller in his book about euthanasia [1]. This author denounces the loss of the "taboo" of the sanctity of human life and, with it, of the reference to something indisputable which is at the base of any ethical discussion. Indeed, if "everything" is questionable, nothing in fact is. Or, as Aristotle said when speaking about the basic axioms of reasoning, the principles of the demonstrations are not, in turn, demonstrable.

Müller puts the finger on the spot, sore now for a very long time, of the bioethics discussion, often noticeable in the "ethical" discourse which has lost the reference to ethos. In fact, in any congress of bioethics -surely, there are some exceptions-, a person

*This document is a reduced and modified version of the work titled "La bioética ha muerto. ¡Viva la ética médica!" (in English: "Bioethics is dead, long live bioethics!"), published in the journal Cuadernos de Bioética, XXVI/1 (2015), pp. 25-49, available at http://aebioetica.org/revistas/2015/26/86/25.pdf. 
armed only with common sense (what the German call gesunder Menschenverstand) would have to assume the onus probandi if he/she wanted to defend that a physician must not kill, since there are professionals who are more qualified to do this (for example, the executioners in charge of killing prisoners sentenced to death in some states of the USA, and who can do so without causing any pain).

This type of pre-discursive perception enables the actual discourse to then stay on track. Since the first abortion laws were passed in the so-called first world, the general intuition that there is something, within this domain, that "is not to be touched" -that is the meaning of the word sacred, the opposite of what is profane- has slowly faded, although, in equal measure, the ethical discourse itself has also progressively lost power. However, if we return to the general intuition of all classical ethical traditions, from Aristotle to Kant, it is precisely the absolute conviction of the existence of principles, axioms or "values", which are out of our reach and power, that guarantees the fundamental sanity of discourse. The rhetorical ineptitude of the person who is unable to "demonstrate" that a physician is not there to kill is, in fact -Müller claims-, his/her best "argument".

I do not know if the current crisis of bioethics is such that the statement of the title of my previous work -i.e., that it "is dead"- can be maintained, but it is more or less clear that there is something rotten in Denmark when so many neurons have to be employed to demonstrate, for example, that the event of birth accomplishes the authentic miracle of turning into human "something" that was not already evidently so (generally, for the previous nine months). Indeed, and although in all cultures the event of birth involves a complex symbology and ritualism, ontologically speaking it is no more than a local change, a passage, the transition from being inside (the maternal womb) to being outside it (i.e. of being born). And, in fact, believing that this simple translocation produces the substantial and significant change of transforming something pre-human into something human, demands the adoption of a highly forced intellectual stance that is completely counterintuitive [2].

However, a mother who talks to her child of the pregnancy stage his/her birth involved, intuitively claims that it was the actual child who was inside her -"inside here", she will say pointing at her belly-, not "something" that then became the child. In the same way that a female elephant is pregnant of an elephant calf, a female cat of a kitten, and a female seal of a pup, a pregnant woman carries a boy or a girl. She is obviously not carrying a baby mouse or a cauliflower: - "It was you" -she will tell her child years later- who was inside here, kicking and doing all the things mothers know so well. -A cyst, or a pimple? as a female minister said some years ago in Spain. -One must be unable to see the woods for the trees to say something like that. $-\mathrm{A}$ mass of cells? $-\mathrm{I}$ am also a mass of cells -although perhaps in my case I can accommodate a few more cells than a human embryo. However, I think I am more than that. A human embryo is a human being in the embryonic stage, i.e. little... but human.

It is also not very encouraging or positive for the good health of common sense, that those who openly conspire against it within the "bioethicist's" profession, have simply adopted the foul language of those who promote the "right to die with dignity". Logic takes its toll and, in good logic, those who defend this alleged "right" are taking for granted a curious identification between "dignity" and "good health", as well as a further identification between "disease" and "indignity".

I would, therefore like to point out that the loss of what Müller refers to as the "taboo" (the unavailability of human life) only leads to a stuttering and senseless discourse. The laws that give free rein to induced abortion and euthanasia pave the way for what has become known as a "slippery slope", which begins by decriminalizing these intrinsically and completely perverse conducts to then acknowledge them as "subjective rights". This produces a mutation of sociomoral parameters, due to the 
regulatory efficiency of the laws, which has unfortunately polluted an important part of the more or less cultured population of the first world. This acknowledgment has intoxicated not only the bioethics profession but also a significant proportion of the healthcare professions.

Should it become normal to think that the choice of a human being is of more value than the life of another human being, this will provide a clear symptom of the dangerous weakening of the essential fibers interweaving the fundamental concepts that feed the legal, political and ethical discourse. This discourse, in the cultural history of the Christian West, has been possible due to certain premises, which are, let's say, not written but rather inscribed within the actual genome of theoretical and practical rationality.

Alejandro Llano offers an interesting reflection on the profound value of human freedom, and how the trivialization of this concept has been transformed into a letter of marque for the dissemination of these viruses, threatening the sociomoral consistency of a civilization which has been a humanistic and humanising reference to other cultural and geographical spaces. Llano exposes "a decisive and generalised anthropological error: the idea that freedom is developed in spontaneous exercise, with no consideration for goods, virtues or rules. The result of this is the caprice, freedom understood as choice, as if it were a matter of choosing superfluous or indigestible products in any supermarket. And this the caprice produces individuals who are castrated in terms of their capacity for evaluation, willing to ravage their lives for the immediate requirements of the market society" [3].

\section{An epistemological outrage}

The epistemological profile shown by the current bioethics discussion in most forums is that of a merely instrumental reasoning entangled in issues regarding the hegemony it should be granted in the decision-making "process", regarding autonomy, justice, beneficence or non-maleficence. So-called "principlism" has resulted in a simplistic presentation of the practice of decision, so abundant in the Anglo-Saxon context of decision-making. In this process, the moral subject could be replaced by a protocol, with the alleged advantages that this would have in terms of operability and functionality.

Greek tragedy is more faithful to reality than what is written or discussed in most academic forums debating bioethics. The "dramatic" essence of the ethical decision more so when the situation may become tragic-, cannot, strictly speaking, be theorised, or only from, let's say, an analytical perspective. It can be theorised but remains more faithfully contained within the mythical-narrative discourse than within decisionmaking protocols, or at least it becomes more difficult to distort [4].

The consequence of the debate's corruption is that the truth is no longer important in the bioethics discourse (at least not in the majority of academic forums where it develops). In the post-truth era, it is becoming evident to many people that discussion is no more than an arm wrestling contest of interests. The interests at stake are collected and counterbalanced. But the human dramas of pain, suffering or death no longer appear, not even distantly, in these power struggles. These human realities are only "managed", with increasing bureaucracy from the social welfare systems, while commercial companies make profitable the business of "industrialised" death.

Bioethics has become a further element of this machinery; either that or an ideological discourse that supports the industry of Thanatos with justifications that provide the business with a neat appearance, a sheen of respectability.

\section{The ethical issue}

Many people think that, like truth, goodness is also relative, and consists of what each person deems good, or convenient for him/her, or of whatever reaches a majority 
consensus. Although this has become the mantra of European cultural forums, a forced intellectual stance is needed to maintain it.

I have attended many bioethics congresses where the use of the words "good" and "evil" is forbidden. They provoke a rejection similar to that achieved by the words "truth" and "falsehood", and due to the same reasons, since good is the truth in its practical sense, the truth that is to be done. In academic settings, one feels obliged to avoid them. However, if you think about it, it is senseless to rule them out of the ethical discourse or, on the whole, of arguments on practical matters. Putting together an ethical discourse without the notions of good and evil is truly absurd. People who still keep their heads on their shoulders realise that these vetoes are false. Even if we undertake the mental restriction of eliminating these notions from our discourse to appear neat and correct in forums that hand out medals to political, ethical or academic correctness, everybody understands what they mean, and they mean a lot. It is indeed likely that these are the first notions that we understand, good and evil, truth and falsehood [5].

Someone can pretend to be a "free-thinker", a "critical" and the guarded person that takes nothing for granted. $\mathrm{He} / \mathrm{she}$ can build a language that avoids these fundamental categories, but although all this may be very presentable, may even be considered a mark of honour in many para-intellectual fields, it does not make him/her more intelligent, but less so. I do not mean to say that people who yield to such a pretence do not think of such categories, but rather that they have to keep quiet about what they think, or say what they do not think, to avoid the rebukes or ostracism decreed by many agencies and "observatories" in charge of suffocating what people think or what they say that they think. (The so-called gender police are now particularly repressive in Europe). All this does not make us more free-thinking but indicates quite the opposite.

Wise discussion -which universities are called to promote- addresses categories and principles derived from our daily contact with reality and people, which structure the ethos, the primary realm of living and thinking. For the most part, these categories and principles appear in the form of preconceptions or prejudices although they enter the forum precisely with the pretence of becoming confirmed concepts and judgements. My master Antonio Millán-Puelles said that philosophy consists of elevating what is proverbial so that it becomes common knowledge. We enter discussion encumbered by preconceptions and prejudices. Kant maintained that reason had to be freed of all assumptions or suppositions. An "absence of presuppositions" (Voraussetzungslosigkeit) in the sense the German master proposes, I believe -in all modesty, of course- is not possible; although it is possible, as well as very desirable, to make sure that they do not remain "mere" suppositions but are contrasted with each other in order to highlight their logical worth. However, there are certain basic suppositions of thought -concepts and judgements- that have axiomatic value, and that cannot be clarified through arguments and must be admitted without doubt or discussion (sine dubitatione et discursu), precisely so that the rational discourse works, i.e. develops and flows from them and not over them. Even if we undertake the mental restriction of telling ourselves: I am going to forget them, I am going to think as if (als $o b)$ they had no value, it is impossible to avoid them. Even relativists, who seem to have a phobia of truth, believe that what they are saying is true when they maintain that truth does not exist: "It is true that truth does not exist". There is no way of thinking something without thinking it true, and there is no way of expressing a thought that does not reveal a pretence of truth. Then one will have to confirm that it is the truth, but in the extent that it is thought, it is inevitable to think it true. Otherwise, what does one do when one thinks? The same applies to the practical employment of reason, whose spontaneous use is implicitly structured by the principle "do the good and avoid the evil" (fac bonum, vita malum), or expressed in an expository manner, "the good is to 
be done and fostered, and evil avoided" (bonum est faciendum et prosequendum, malum vitandum), the possession of which the followers of Saint Thomas named "sinderesis". This is so obvious that it goes without saying.

It would seem that the entire academic profession of bioethicists insists on developing a discourse that is no more than an artificial construct, intent on avoiding and eliminating the axiom that a physician must not deprive human beings of their life. Some, perceived or real, followers of Kant, with a part of Kant's legacy at hand, try to build an intellectual argument that can defend this or the opposite stance. And it is impossible to conduct a serious discussion in this way.

I think that the purpose of the ethical discussion is not to reach an agreement or consensus. But in order to conduct a serious discussion, it is necessary to agree on certain basic matters, not at the end but at the beginning of the discussion. That a physician is not there to euthanize or to perform abortions is a starting and not an arrival point. From this understanding, we can and must go on to discussing other matters. However, if the general agreement in bioethics -and it seems to be the only existing agreement- is to consider debatable the prohibition of killing and to applaud the people who question this, then the axiom that enables a moderately sound discussion breaks down. In order to reach this stage, it is necessary for the concepts of good and evil -or of truth and falsehood, respectively-, as well as the basic axioms of the theoretical and practical use of reason -the principle of non-contradiction, or that good is to be done and fostered and evil avoided-to disappear or become meaningless, i.e. reason must be cancelled, or its use reduced to a mere strategy.

The core proposal of the previous paragraphs is in line with the restoration of the "ethical" profile of bioethics based on the reference to ethos, still present in the helping professions, especially in the medical profession. Although the profession is haunted by the virus described, it still works under a truly ethical atmosphere, thanks to the ideals of the Hippocratic tradition. The lifeworld (Lebenswelt) is still maintained with certain vigour by real people who try to help other concrete individuals -patients-, within a structure of meaningful practices (sinvoller Handlungen) and linguistic forms that are semantically "strong", truly significant.

Robert Spaemann has shown on many occasions that ethos is no derived from ethics -like discourse is-, but on the contrary. Aristotle was able to see this in all its seriousness. So was Kant. And Alasdair Macintyre has seen it in his own way by indicating, in opposition to liberal authors, that justice cannot be defined independently of the practical particularities of individuals. Reconstructing this ethos from what Macintyre calls the "internal goods of practice" is, I think, the hope that bioethics may rise from its ashes. Physicians with a conscience know more about ethics than most "expert bioethicists".

\section{References}

1. Tötung auf Verlangen. Wohltat oder Untat?, Reclam, Stuttgart, 1997.

2. In a recent book I have shown the futility with which, within this context, it is normally claimed that the human embryo is "potentially" a human being. Vid. Barrio, J.M., Metafísica para gente corriente (in English: Metaphysics for ordinary people), Rialp, Madrid, 2017; 134-140.

3. Cfr. Llano, A., Maravilla de maravillas: conocemos (in English: Wonder of wonders: we know), Eunsa, Pamplona, 2016, p. 39. "As Elizabeth Anscombe indicated at the time, the stance at the basis of most errors is 'emotivism'. The starting point is something which is, simply, not true: the immediacy of moral perception, where ethical attitudes are viewed as objects of individual preference, unyielding to any moral basis. We are confronted with freedom understood as choice, as an option or election between many available possibilities, as if they were a range of articles displayed in a supermarket. Pro-choice would be the only behaviour worthy of mature and reasonable individuals in a democratic society, and even the pro-life stance would be subject to it. Well, it happens to be that this understanding of choice has no maturity or reason of any kind: it is only a spontaneity that, more than anything else, reveals infantilism" (p. 17). 
4. In Poetics, Aristotle clearly saw the exemplary value of myths. Usually, stories have a more exemplary and cathartic force than ethical arguments. In any case, it is positive that the former precede and accompany the latter.

5. The followers of Aristotle talk of the habitus principiorum, the intellectual "having" at the root and base of every discourse, i.e. the cognitive possession of the first and most basic principles of reason. They consider that the habit of principles is an intellectual virtue, "dianoethics". Saint Thomas Aquinas explains that it is not an intellectual act, but rather the implicit, common knowledge of certain fundamental axioms which in turn presuppose certain first concepts, which are in the genome, in the profound structure of any intellectual use, whether theoretical or practical. This category includes the concept of being and its transcendental properties -with truth and goodness among them-, the principles of non-contradiction, of identity, of excluded middle, etc. 